In Good Faith 



\title{
IN GOOD FAITH
}

\author{
Arabic Translation \\ and Translators \\ in Early Modern Spain
}

Claire M. Gilbert

\section{PENN}

UNIVERSITY OF PENNSYLVANIA PRESS 
Copyright (C) 2020 University of Pennsylvania Press

All rights reserved. Except for brief quotations used for purposes of review or scholarly citation, none of this book may be reproduced in any form by any means without written permission from the publisher.

\author{
Published by \\ University of Pennsylvania Press \\ Philadelphia, Pennsylvania 19104-4112 \\ www.upenn.edu/pennpress
}

Printed in the United States of America on acid-free paper

$\begin{array}{llllllllll}13 & 5 & 7 & 9 & 10 & 8 & 6 & 4 & 2\end{array}$

A Cataloging-in-Publication record is available from the Library of Congress

ISBN 978-0-8122-5246-0 
For my family, whose faith in this project has made everything possible. 
